\title{
CHANGES IN THE PLASMA LEVEL OF SOME HYDROLYTIC ENZYMES DURING THE RESORPTION OF CESTROGEN-INDUCED MEDULLARY BONE IN COCKS
}

\author{
K.-M.-L. MORRIS $\left({ }^{1}\right)$ and T.-G. TAYLOR $\left({ }^{2}\right)$ \\ Agricultural Research Council's Poultry Research Centre, \\ King's Buildings, West Mains Road, Edinburgh 9 (Great-Britain)
}

\section{INTRODUC'TION}

The biochemical mechanisms by which bone is resorbed are not fully understood. It is generally assumed, however, that the mineral matter is removed under the influence of locally-produced acids and that the organic matter is solubilized by enzymic mechanisms. Acid hydrolases of 1ysosomal origin have been implicated in the process of bone resorption in organ culture (VAES, I965), and it was considered that a study of the activity of some lysosomal enzymes in plasma during the resorption of sestrogen-induced medullary bone might provide in vivo evidence for or against the participation of these enzymes in the process of bone resorption, on the assumption that changes in the activities of these enzymes in the bone might be reflected in their activities in the plasma. Formation of medullary bone is readily induced in cocks by œstrogen administration and resorption occurs when the hormone is withdrawn (URIST, I959).

\section{MATERIAIS AND METHOD}

\section{Birds and treatments}

Fifteen medium hybrid cockerels (Thornber 404) 12-weeks of age and weighing 1.6-2.0 kg, were used in this experiment. Eight of the birds received I I intramuscular injections of œstradiol dipropionate (Ovocyclin $\mathrm{P}$, Ciba) at a level of $\mathrm{I} \mathrm{mg} / \mathrm{kg}$ body weight administered on alternate days, while the remaining 7 birds, acting as controls, were injected with the carrier oil.

Blood samples $(5 \mathrm{ml})$ were taken from the wing vein into a heparinized syringe on day of

(1) Present address : Barking Regional College of Technology, Dagenham, Essex (Great Britain).

( ${ }^{2}$ Present address: Department of Physiology and Biochemistry, The University, Southampton, So $95 \mathrm{NH}$ (Great Britain). 
(the day before the first injection) and on days $7, \mathbf{I}_{4}$ and $2 \mathrm{r}$, during which time medullary bone formation was taking place. The last injection was on day $2 I$ and further blood samples were taken on days $25,29,33$ and 39 .

One control and one œestrogen-treated bird were killed on day $2 \mathrm{I}$ and another of the ostrogen-treated cocks was killed on day 29. One femur from each of these birds was taken for histological examination.

\section{Analytical methods}

The blood was centrifuged immediately and the plasma analyzed for total calcium (HERTELENDY and TAYLOR, I96I), acid and alkaline phosphatase (BELl and Siller, I962) aryl sulphatases A and B (Roy, I953) and $\beta$-glucuronidase (Fishman, Springer and Brunetti, I948).

\section{RESULTS}

\section{Bone histology}

Large amounts of medullary bone were observed in the femur of the bird killed at the end of the period of ostrogen administration but none was present in the femur of the control cock. The bird killed 8 days after the last injection of hormone still possessed substantial amounts of medullary bone but the spicules were thinner, presumably due to resorption, and it was evident that there was less bone tissue per unit area than in the cock killed 8 days earlier.

\section{Plasma calcium}

The level of total calcium in the plasma of the œstrogen-treated birds rose from a mean of $12.0 \mathrm{mg} / \mathrm{roO} \mathrm{ml}$ to $87.6 \mathrm{mg} / \mathrm{roO} \mathrm{ml}$ at day $\mathrm{I}_{4}$ and it remained at this level until the end of the injection period. Little variation occurred in the control group. Four days after the last injection the mean level was $35.1 \mathrm{mg} /$ Ioo $\mathrm{ml}$ and normal levels were not restored until day 33 (table I).

TABLE I

Mean levels of total plasma calcium ( $\mathrm{mg} / \mathrm{I}$ oo $\mathrm{ml}$ ) in cocks before, during and after 21 days of oestrogen treatment (Means \pm S. E.)

\begin{tabular}{c|c|c}
$\begin{array}{c}\text { Day of } \\
\text { experiment }\end{array}$ & $\begin{array}{c}\text { Control } \\
7 \text { birds }\left({ }^{1}\right)\end{array}$ & $\begin{array}{c}\text { Oestrogen-treated } \\
8 \text { birds }\left({ }^{2}\right)\end{array}$ \\
\hline & - & $12.0 \pm 0.3$ \\
0 & $11.3 \pm 0.3$ & $48.7 \pm 2.6$ \\
7 & $11.7 \pm 0.3$ & $87.6 \pm 4.6$ \\
14 & $11.7 \pm 0.4$ & $88.8 \pm 3.8$ \\
21 & $11.5 \pm 0.4$ & $35.1 \pm 4.7$ \\
25 & $11.5 \pm 0.3$ & $17.5 \pm 1.3$ \\
29 & $11.4 \pm 0.3$ & $13.3 \pm 0.6$ \\
33 & $11.4 \pm 0.3$ & $12.1 \pm 0.3$ \\
39 & & \\
\hline
\end{tabular}

(1) One killed on day 21.

(2) One killed on day 21 and another on day 29. 
It must be assumed that the birds were under the influence of œstrogen until the plasma calcium had fallen to a level not significantly different from the preinjection level and that bone resorption was not proceeding for certain until that time.

\section{Plasma alkaline phosphatase}

The activity of this enzyme varied slightly from bleeding to bleeding, but at no time did the mean value differ significantly from the value at day o. Somewhat greater fluctuations occurred in the treated group from the day of the last injection, but even the highest mean value (on day 29) did not differ significantly from the initial value.

In order that the changes in the plasma levels of this enzyme (and of the acid hydrolases also) might be compared in the different physiological conditions, the mean values for days 7 , I4 and $2 \mathrm{I}$, when the birds were under the influence of ostrogen have been calculated and these values are presented in table 2 together with the values for the two final bleedings when bone resorption can be assumed to have been taking place. All these means are expressed as percentages of the mean values at the start of the experiment (day o).

\section{Plasma acid hydrolases}

The activity of all the acid hydrolases studied decreased significantly during the period of ostrogen treatment in relation to the pre-injection levels and the reduction in $\beta$-glucuronidase and aryl sulphatases was greater than the reduction in acid phosphatase (table 2). After the withdrawal of the hormone the activity of all three enzymes increased sharply, but only in the case of acid phosphatase did the level rise above the pre-injection level.

\section{TABLE 2}

Changes in the activities of plasma enzymes during oestrogen treatment and during the bone resorption occurring when oestrogen was withdrawn

Values are means for 7 or 8 birds expressed as percentages of the pre-treatment levels of activity. The control birds were not injected with oestrogen

\begin{tabular}{|c|c|c|c|c|c|c|}
\hline \multirow{3}{*}{$\begin{array}{c}\begin{array}{c}\text { Physiological } \\
\text { state }\end{array} \\
\frac{\text { Days of experiment } \ldots \ldots}{\text { Enzyme } \ldots \ldots \ldots \ldots}\end{array}$} & \multirow{2}{*}{\multicolumn{2}{|c|}{$\begin{array}{c}\begin{array}{c}\text { Oestrogen } \\
\text { treatment }\end{array} \\
7,1^{\prime} \text { t and } \mathbf{2 1}\end{array}$}} & \multicolumn{4}{|c|}{ Bone resorption } \\
\hline & & & & 3 & & \\
\hline & Control & Oestrogen & Control & Oestrogen & Control & Oestrogen \\
\hline $\begin{array}{l}\text { Alkaline phosphatase } \ldots \ldots \\
\text { Acid phosphatase } \ldots \ldots \\
\text { Aryl sulphatases } \ldots \ldots \\
\beta \text {-glucuronidase } \ldots \ldots\end{array}$ & $\begin{array}{r}101 \\
104 \\
105 \\
82\end{array}$ & $\begin{array}{l}96 \\
67\left(^{1}\right) \\
31\left(^{1}\right) \\
28\left(^{1}\right)\end{array}$ & $\begin{array}{l}92 \\
83 \\
85 \\
79\end{array}$ & $\begin{array}{l}116 \\
149\left({ }^{1}\right) \\
77 \\
58\end{array}$ & $\begin{array}{l}92 \\
86 \\
72 \\
75\end{array}$ & $\begin{array}{c}95 \\
156(\mathbf{l}) \\
80 \\
92\end{array}$ \\
\hline
\end{tabular}

(1) Significantly different from corresponding control value $(p<0.001$, ' $t$ ' test). 


\section{DISCUSSION}

Of the hydrolases studied only the sulphatases are located solely in the lysosomes. Acid phosphatase and $\beta$-glucuronidase, besides being present in the lysosomes, are found elsewhere in the cell. Nevertheless, the activity in the plasma of all these enzymes was substantially reduced under the influence of ostrogen and it is possible that this was due to a stabilizing effect of the hormone on the lysosomal membranes (WILLMER, I96I). The decline in acid phosphatase was much less than that of the other two acid hydrolases studied, which suggests that, under normal conditions, much of the plasma acid phosphatase arises from sources other than the lysosomes. It is not possible to relate these changes specifically to the formation of new bone since œstrogens induce the most profound changes in the metabolism of the liver as well as the bone.

Once the effects of the œstrogen had worn off and the level of plasma calcium had returned to normal, the most important physiological respect in which these birds differed from normal was in the resorption of medullary bone. The only plasma component which showed a significant difference between the ostrogen-treated and control birds at this time was acid phosphatase and it would appear that bone resorption is associated with the release of this enzyme into the blood, thus confirming the observations of TAYLOR, WILLIAMS and KIRKLEY (1965) and MORRIS and TAYLOR (I970) with laying hens. 'The bone cells most likely to liberate acid phosphatase are osteoclasts and mature osteocytes both of which are rich in lysosomes. The biochemical role of acid phosphatase in bone resorption is not clear, however.

\section{ACKNOWLEDGEMENT}

We wish to thank Dr W.-G. SILlER for carrying out the histological examination of the bones.

\section{SUMMARY}

Plasma levels of acid and alkaline phosphatases, aryl sulphatases and $\beta$-glucuronidase were studied in 8 cocks before, during and after the intramuscular injection of œstrogen. Alkaline phosphatase did not show any significant changes but the levels of all three acid hydrolases were significantly depressed during the period of cestrogen treatment. Following the withdrawal of the hormone the activities of the acid hydrolases increased, but only in the case of acid phosphatase was the level raised above the pre-injection level, suggesting that this enzyme is released into the blood during bone resorption. 


\section{RÉSUMÉ}

\section{VARIATION DE LA CONCENTRATION PLASMATIQUE DE QUELQUES ENZYMES HYDROLYTIQUES DURANT LA RÉSORPTION DE L'OS MÉDULLAIRE INDUIT PAR LES GESTROGËNES CHEZ ILE COQ}

Les concentrations plasmatiques des phosphatases acides et alcalines, des arylsulphatases et de la $\beta$-glucuronidase sont étudiées chez $8 \mathrm{coqs}$ avant, durant et après l'injection intramusculaire d'œstrogènes. La phosphatase alcaline ne change pas, mais les niveaux des trois hydrolases acides sont significativement réduits durant le traitement aux œestrogènes. L'activité de ces hydrolases remontent dès que le traitement cestrogénique est arrêté mais le niveau ne đevient supérieur à celui avant injection que pour la phosphatase acide, ce qui suggère que cet enzyme est libéré dans le sang durant la résorption osseuse.

\section{REFERENCES}

Bell D. J., Siller W. G., I962. Cage layer fatigue in Brown Leghorns. Res. vet. Sci., 3, 2 19-230.

Fishman W. H., Springer B., Brunetti R., I948. Application of an improved glucuronidase assay method to the study of human blood $\beta$-glucuronidase. J.biol. Chem., 173, 449-456.

Hertelendy F., Taylor T. G., I96I. Changes in blood calcium associated with egg shell calcification in the domestic fowl. Poultry Sci., 40, I08-II4.

Morris K. M. L., TAYlor T. G., I970. Urinary excretion of hydroxyproline and acid phosphatase in relation to egg shell formation in the domestic fowl. Ann. Biol. anim. Bioch. Biophys., 10, $\mathrm{n}^{\circ}$ hors série 2, 185 -I 90 .

Roy A. B., I953. The sulphatases of ox liver. Biochem. J., 53, r2-I5.

Taylor T. G., Williams A., Kirkley J., I965. Cyclic changes in the activities of plasma acid and alkaline phosphatases during egg shell calcification in the domestic fowl. Canad. J. Biochem., 43, 45I457.

URIST M. R., I959. The effects of calcium deprivation upon the blood, adrenal cortex, ovary and skeleton in the domestic fowl. Rec. Prog. Hormone Res., 15, 455-477.

VAES G., 1965. Excretion of acid and of lysosomal hydrolytic enzymes during bone resorption induced in tissue culture. Exp. Cell., Res., 39, 470-474.

Willmer E. N., ig6r. Steroids and cell surfaces. Biol. Rev., 36, 368-398. 